Шевчук В.П., доктор історичних наук, професор, головний науковий співробітник науково-дослідного иентру воєнної історії НУО України імені Івана Черняховського (м. Küв)

\title{
ІСТОРІОГРАФІЯ СТВОРЕННЯ ТА РОЗВИТКУ ЗБРОЙНИХ СИЛ УКРАЇНИ В 1991-2014 РОКАХ
}

У статті висвітлюеться прочес нагромадження історичних знань про створення та розвиток Збройних Сил України у 1991-2014 роках. Аналізуються переважно дослідження з історії створення видів Збройних Сил, які суттєво розширили та поглиблили вітчизняну військову історіографію. Розглядаються наукові праџі, в яких йдеться про упущення та недоліки у будівництві Збройних Сил Украйни, наслідки яких безпосередньо вплинули на тимчасове ослаблення бойових спроможностей військ в умовах російської збройної агресії проти України.

Ключові слова: Збройні Сили Украӥни, історіографія, наукові видання, дисертаційні дослідження, види Збройних Сил, боєздатність, створення, розвиток.

У системі забезпечення обороноздатності України, в гарантованому захисті їі державної незалежності вирішальна роль належить ï Збройним Силам. Конституція України покладає на Збройні Сили завдання оборони держави та захисту іï суверенітету, територіальної цілісності і недоторканності. У процесі розбудови державних структур незалежної України Збройні Сили у своєму становленні в 1991-2014 роках пройшли складний та непередбачуваний розвиток. У їх будівництві нагромаджувався позитивний досвід і водночас мали місце упущення та суттєві прорахунки, 
що далися взнаки у відповідальний період захисту України від збройної агресії Російської Федерації [1].

Однією 3 передумов 3'ясування причин тимчасового ослаблення боєздатності Збройних Сил та визначення напрямів їх подальшого розвитку відповідно до викликів сучасності мають стати історіографічні дослідження, критичний аналіз наукових праць, що відтворюють процес становлення їх у системі забезпечення обороноздатності України. Завдяки такому підходу створюється можливість відтворити набутий досвід, виявити помилки у процесі становлення Збройних Сил держави з тим, щоб унеможливити їх повторення на сучасному етапі військового будівництва.

Мета статті полягає в аналізі наукових праць вітчизняних авторів зі створення та розвитку Збройних Сил України у хронологічних межах 19912014 років.

Військово-історичні знання про створення та розвиток Збройних Сил України нагромаджувалися у три етапи, кожен з яких має свої особливості, обумовлені ступенем охоплення наукової проблеми, іï актуальністю, використанням інформативних джерел, теоретичним та практичним вирішенням предмета дослідження. На першому етапі, що охоплює 19911997 роки, у наукових та науково-популярних працях обгрунтовувалася суспільна ідея необхідності Україні мати власні Збройні Сили, аналізувалися перші законодавчі документи про створення Збройних Сил. Досягненням історіографії цього етапу стало наукове обгрунтування положення про створення в Україні основи Збройних Сил станом на 1996 рік.

На другому етапі історіографії з 1997 року зусилля науковців зосереджувалися на висвітленні процесів та завдань, визначених у державних програмах реформування та розвитку Збройних Сил. 32014 року розпочався третій етап розвитку історіографії, який характеризується аналізом стану Збройних Сил України напередодні російської збройної агресії проти України, висвітленням шляхів зміцнення боєздатності Українського війська 
під час виконання завдань антитерористичної операції та операції Об’єднаних сил.

Одним із перших звернувся до історіографії створення Збройних Сил України В. Л. Папікян. У статті “До історії будівництва Збройних Сил України (1991-1996рр.)” автор проаналізував первинні публікації з цієї тематики [2, с. 121-129]. Характеристику наукових праць, переважно політологічного та соціологічного змісту, в яких розглядаються аспекти формування Збройних Сил України, провів В. С. Чорний [3]. Колишній очільник військового відомства О. І. Кузьмук у монографії аналізував праці, в яких відображено створення Збройних Сил у контексті формування та розвитку воєнної організації України, перетворення іï у сектор безпеки та оборони держави [4].

Уже перші наукові видання доводили, що передумовою створення Збройних Сил України став розгорнутий наприкінці 80-х - початку 90-х рр. ХX ст. національно спрямований політичними, громадськими та релігійними організаціями суспільний рух за відродження української державності та піi збройних сил як гаранта зовнішньої безпеки незалежної держави [5].

Історіографічний процес у сфері основних тенденцій формування Збройних Сил України в перші роки незалежного розвитку держави комплексно проводив О. І. Покотило. У своїй кандидатській дисертації автор розглянув праці, в яких йдеться про військову спадщину України в результаті розпаду Радянського Союзу, становлення Збройних Сил України, комплектування їх офіцерськими кадрами та формування вищих органів військового управління. Автор підтвердив твердження дослідників про те, що станом на 1996 рік в Україні були створені основи Збройних Сил держави [6, с. 14-15]. Надбанням вітчизняної історіографії стала колективна праця військових фахівців “Збройні Сили України. Перші 10 років (1991-2001)”, у якій у хронологічних межах розглядаються умови становлення видів Збройних Сил України [7]. 
Суттєво збагатили історіографію дисертаційні роботи та наукові праці, підготовлені ад'юнктами та здобувачами, що присвячені історії створення видів ЗС України. Вони виділяються тим, що розглядають створення видів Збройних Сил 3 позицій україноцентризму та використанням архівних матеріалів. У працях I. І. Сокаль та В. Г. Куравського доводиться, що 3 початком військового будівництва в незалежній Україні чисельність підготовленого особового складу, наявність військової техніки та ï якісний стан в цілому сприяли створенню Повітряних Сил як нового виду Збройних Сил України [8, с. 50-53; 9, с. 37-41]. Однак погляди та підходи вищого державного та військового керівництва України впродовж 1991-2005 років щодо створення повітряної складової Збройних Сил мали непослідовний та неузгоджений характер. Суперечливе ставлення державного керівництва до створення нового виду ЗС України відображено у працях О.Стеценка, В. Ткачова, В. Камінського. Президент України Указом від 27 травня 1992 року № 310/92 визначив четвертий вид Збройних Сил - Війська Протиповітряної оборони (ППО), який не передбачали тогочасні законодавчі акти Верховної Ради України. Відсутність узгодженої позиції щодо створення нового виду Збройних Сил, відповідального за оборону повітряного простору держави, безпосередньо вплинула на тривалість процесу становлення Повітряних Сил Збройних Сил України.

У 1991-2005 роках зроблено дві спроби створення нового виду на основі об'єднання ВПС (Військово-Повітряних Сил) та Військ ППО (Протиповітряної оборони). Перша спроба відбувалась у 1991-1994 роках під назвою Військово-Повітряні Сили України, друга - у 1995-1996 роках як Війська Повітряної оборони України. Тільки через одинадцять років незалежного розвитку держави законодавча і виконавча гілки влади дійшли до спільного розуміння, що дало змогу 12 квітня 2002 року колегії Міністерства оборони України на виконання вимог Президента України ухвалити програму об'єднання Військово-Повітряних Сил та Військ Протиповітряної оборони і на їх основі приступити до створення Військово- 
Повітряних Сил як нового виду Збройних Сил України [10]. У наукових працях доводиться, що у процесі створення Військово-Повітряних Сил розпочалася їх структурна перебудова та оптимізація передусім кількісних показників.

Iз змісту наукових досліджень випливає, що процес створення Військово-Морських Сил України (ВМС України) виявився складним і напруженим, проходив в умовах українсько-російського політичного протистояння. Україна вже у квітні 1992 року заклала правову базу відродження українського флоту. Ї̈̈ зміст розглянуто у дослідженнях

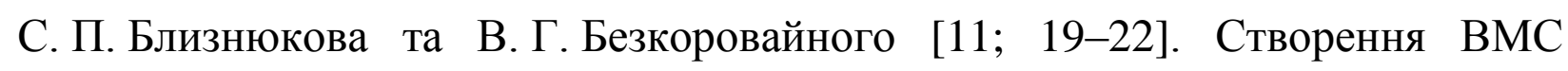
України автори розглядають 3 позицій російсько-української угоди, підписаної у серпні 1992 року, яка передбачала формування ВМС України на основі розподілу Чорноморського флоту колишнього СРСР, однак домовленості не були реалізовані. Системно розкрив історію створення основ ВМС України у своій кандидатській дисертації О. О. Нашивочніков [12]. Автор доводить, що українсько-російські угоди (Ялтинська, Дагомиська та ін.) не визначали реалій створення ВМС України на базі Чорноморського флоту колишнього СРСР. Виникла складна і непередбачувана ситуація, що характеризувалася неможливістю створення Українського флоту на базі дислокованого на українській території Чорноморського флоту. Україні довелося формувати ВМС на наявній, хоча і незначній, власній матеріальнотехнічній базі. Особовий склад забезпечувався військовослужбовцями, які прийняли присягу на вірність народу України. Завдяки такому підходу вдалося уникнути протистояння навколо Чорноморського флоту та зосередити головні зусилля саме на потребах ВМС України. У 1991-1994 pp. сформовано фундамент ВМС України як нового виду Збройних Сил України: створено органи військового управління, розроблено структуру та розпочато формування родів військ (сил) флоту, реалізовувалися заходи оперативної та бойової підготовки. 
Однак, як доводять дослідники, на етапі формування основ ВМС України не вдалося реалізувати заходи, що передбачали створення збалансованих за особовим складом сил та необхідним корабельним потенціалом, озброєнням і військовою технікою; затягувалося формування системи базування та всебічного забезпечення, розвиток концептуальних поглядів на завдання і засади стратегічного й оперативного застосування Українського військового флоту. Своєчасно не було призначено командувача Українським військовим флотом.

В офіційних документах України, присвячених військовому будівництву, стверджувалося, що у виконанні завдань із забезпечення обороноздатності держави першочергова роль відводилася Сухопутним військам, які були найбільш чисельними, складалися із різних родів військ і становили основу бойового потенціалу Збройних Сил держави. Вітчизняна історіографія становлення Сухопутних військ розглядала переважно у загальному контексті створення Збройних Сил України. Такий підхід характерний для праць В. Бринцева, О. Смирнова, Р. М. Фарадея, присвячених становленню Сухопутних військ [7].

Системно розкрив процес створення та розвитку Сухопутних військ України в 1991-2005 роках військовий фахівець Г. П. Воробйов. У своїй дисертаційній роботі автор показав, що базою для створення Сухопутних військ України стали військові формування радянських сухопутних військ, що дислокувалися на українській території до розпаду Радянського Союзу [13]. На першому етапі військового будівництва в Україні були ліквідовані військові округи, проведено перехід на оперативно-територіальну систему будівництва армії, запроваджено принцип регіонального комплектування армії. Водночас Г. П. Воробйов відзначив, що управління Сухопутних військ України впродовж 1991-2005 років було нестабільне, сім разів змінювалась назва та організаційна структура органів управління. Таке упущення випливало із того, що Воєнна доктрина України, прийнята 19 жовтня 1993 року, окреслила мету й основні напрями будівництва Збройних Сил, але 
не визначила структуру їх видів, i тому не стала помітним поштовхом у створенні Сухопутних військ та забезпеченні їх управління.

Державне та військове керівництво України упродовж п’яти років не мало узгодженої позиції щодо створення функціонального командування цього виду Збройних Сил. У перші роки Сухопутні війська організаційно та адміністративно підпорядковувалися Міністерству оборони України, а невдовзі були передані Головному (Генеральному) штабу Збройних Сил України. Через відсутність функціонального командування затягувалося розроблення організаційно-штатної структури з’єднань і частин Сухопутних військ. В умовах зростання обсягів і завдань Сухопутних військ питання про створення безпосереднього органу їх управління стало предметом публічного обговорення у військовому середовищі [14]. У ході дискусії з’ясувалося, що Сухопутні війська як окремий вид повинні мати відповідний орган управління. Указом Президента України "Про Сухопутні війська України" від 23 травня 1996 року № 368 для більш якісного реформування військ, оперативного керівництва та підвищення їх бойової готовності у структурі Збройних Сил України створено Командування Сухопутних військ [15].

Формування кадрових органів Збройних Сил України, визначення підходів та їх реалізацію у процесі комплектування посад вищого офіцерського складу досліджував О. І. Дашкевич. Автор врахував теоретичні та прикладні напрацювання з цієї тематики військових фахівців К. Морозова, В. Гречанінова, А. Лопати, Є. Марчука, Г. Живиці, В. Лазоркіна. Дослідник 3'ясував військово-політичні фактори та встановив їх вплив на створення кадрових органів Збройних Сил, розкрив зміст, складові та особливості діяльності кадрових органів в умовах формування посад вищого офіцерського складу [16].

Водночас дослідник виявив чинники, що негативно впливали на діяльність структур Збройних Сил України, головними 3 яких були: домінування суб'єктивного підходу при прийнятті кадрових рішень, надання переваги в їх діяльності процесам інтенсивного скорочення 
військовослужбовців, озброєння та військової техніки. Спираючись на фактичні матеріали, автор відмітив, що при відборі кадрів на вищі керівні посади не повною мірою враховувалися їх моральні якості та компетентність. Призначення часто-густо залежали від політичних поглядів вищестоящих керівників, що негативно впливало на імідж та життєдіяльність підрозділів Збройних Сил України.

3 урахуванням змісту напрацювань своїх попередників (Я. Я. Романовського, Т. В. Іщенка, О.І.Поповича, Г. Д. Темка) військовий фахівець А. О. Кобзар комплексно розглянув становлення структур виховної роботи у ЗС України, запропонував авторську періодизацію цього процесу, позитивно оцінив роль сформованої соціально-психологічної служби, характерною рисою діяльності якої став відхід від заідеологізованого проведення у військах виховних заходів [17]. У той же час дослідник виявив чинники, які негативно впливали на становлення та діяльність структур виховної роботи Збройних Сил України. До них віднесено вкрай обмежене фінансування гуманітарної складової у сфері забезпечення, поспішне реформування організаційних структур виховної роботи та векторів їх діяльності, номенклатурний підхід до формування та визначення завдань, що обмежували вплив державних структур і громадських організацій на духовне життя військовослужбовців та членів їхніх сімей. Поетапне скорочення штатної чисельності структур виховної роботи призводило до втрати роками напрацьованого кадрового та інтелектуального потенціалу. Дослідник вважає, що в діяльності структур виховної роботи визначальне місце мало б належати національним підходам та напрямам військового виховання, що утверджувалися упродовж української військової історії; недопущенню прямолінійного копіювання та перенесення у Збройні Сили України досвіду структур та напрямів виховання військовослужбовців європейських країн.

Із аналізу історіографії випливає, що в 1991-1996 роках в Україні були створені основи Збройних Сил: ухвалена законодавча база, що визначала реформаторські шляхи формування Збройних Сил, створено вищі органи 
військового управління - Міністерство оборони та Головний (Генеральний) штаб Збройних Сил України; опрацьована система їх кадрового забезпечення; прийнята військовослужбовцями присяга на вірність народу України, що створило юридичні (правові) підстави для проходження ними військової служби в ЗС України та позбавило Україну від участі у колективних збройних силах, запропонованих Російською Федерацією; залучено до діяльності Збройних Сил України проукраїнськи налаштованих генералів, адміралів та офіцерів колишніх Збройних Сил СРСР, що забезпечило формування вищого офіцерського корпусу Української армії. Нормативно врегульовано проходження військової служби, розроблені форма одягу, символіка та відзнаки військовослужбовців. Відбулося міжнародне визнання Збройних Сил України, підрозділи яких стали залучатися до міжнародних військових навчань та участі у міжнародних миротворчих операціях.

Водночас у наукових працях доводиться, що створення основ Збройних Сил проводилося без належного наукового супроводу, наявності досвіду та обмеженого фінансування, а безсистемне скорочення особового складу призвело до помітного зменшення бойових частин порівняно з частинами забезпечення. Концепція оборони і будівництва Збройних Сил України, прийнята 11 жовтня 1991 року, визначила оптимальну чисельність військ на рівні 0,8-0,9\% від кількості населення України, що мала становити 400-420 тис. осіб [18]. Таке визначення підкріплювалося досвідом військового будівництва найбільш розвинених країн світу. Однак уже наприкінці 2005 року штатна чисельність Збройних Сил України становила 245 тис. осіб, що стало наслідком їх прискореного скорочення [19, с. 4].

У наукових дослідженнях стверджується, що заявлений державним керівництвом принцип поступового переходу до професійної армії належно не реалізовувався. Сформовані Міністерство оборони України і Головний штаб (з лютого 1994 року - Генеральний) не мали відповідних законодавчих рішень щодо їх функції, що було причиною дублювання їх діяльності. Тільки 
у січні 1997 року Указом Президента України були затверджені Положення про вищі органи військового управління, що дало змогу чіткіше розподілити повноваження між Міністерством оборони та Генеральним штабом Збройних Сил України [20, с. 15]. Негативно впливала на сталість управління військами часта зміна вищого військового керівництва: впродовж 1991-1996 років на посаді Міністра оборони змінилося три особи і чотири начальники Головного (Генерального) штабу Збройних Сил України.

У низці наукових праць та документальних джерелах, що зберігаються у Галузевому державному архіві МО України, доводиться, що деструктивний вплив на формування Збройних Сил України здійснювало державне i військове керівництво Російської Федерації. Щоб дестабілізувати суспільнополітичну та військову ситуацію в Україні, відразу ж після проголошення незалежності прес-секретар російського президента П. Вощанов заявив про можливість перегляду кордонів з пострадянськими державами [21, с. 106]. Московське керівництво не полишало надії зберегти під своїм впливом збройні сили, що формувалися в колишніх радянських республіках, зокрема в Україні. Намагаючись позбавити пострадянські держави власної армії, Президент СРСР 23 липня 1991 року видав Указ про заборону створення збройних формувань у новостворених державах, посилаючись на радянське законодавство, а створені військові формування наказав розпустити. У січні 1992 року Президент РФ Б. Сльцин видав указ про передачу під юрисдикцію Росії всіх збройних сил колишнього СРСР [22, с. 151].

Спекулюючи тезою про потребу гарантувати колективну безпеку пострадянських держав, з Москви в незалежну Україну надходили накази 3 вимогою приведення Українського війська, яке структурно формувалося, до присяги на вірність Співдружності Незалежних Держав (СНД). Генераллейтенант Г. В. Живиця, який працював у Генеральному штабі Збройних Сил СРСР і був обізнаний з поглядами вищого військового керівництва Росії, стверджує, що у вересні 1991 року у Російському центральному військовому відомстві панувала думка, що хоч у республіках створюються міністерства 
оборони, але за будь-яких умов мають залишитися “єдині Збройні Сили i єдиний Генеральний штаб, звичайно, у Москві” [23, с. 72-77]. Військове відомство Росії вимагало від командувачів військових округів, розміщених в Україні, заборонити офіцерам будь-які контакти 3 владними структурами України, а тим більше співробітництво з призначеним Президентом України Міністром оборони України К. П. Морозовим та його оперативною групою.

Особливо відкриту антиукраїнську позицію зайняло державне та військове керівництво Росії під час формування Військово-Морських Сил України. При цьому здійснювався тиск на Україну заради досягнення вигідного для Росії рішення, яке б гарантувало іiі вплив на Кримському півострові. У липні 1993 року російська Дума прийняла провокаційне рішення про Севастополь як базу російського флоту i адміністративну одиницю Російської Федерації [24]. Командування Чорноморського флоту безпосередньо чинило опір формуванню Українського флоту, переслідувало військових, які добровільно складали присягу на вірність народу України [25].

3 метою дестабілізації процесу становлення Української армії, підриву iï ресурсної бази державне керівництво Росії з січня 1992 р. заборонило своїм відомствам постачати в Україну паливно-мастильні матеріали, що призначалися для експлуатації військової техніки [26]. Ряд проросійськи налаштованих генералів і офіцерів, які займали командні посади у військах, розташованих в Україні, сприяли самочинному вивезенню з української території в Росію військової техніки, озброєння та військового майна [27]. Росія без погодження 3 українською владою порушила домовленості про будівництво на території України 17 житлових містечок для сімей офіцерів, військові частини яких виводилися зі Східної Німеччини [28]. Натомість виділені німецькою стороною фінанси московське керівництво зосередило для потреб Росії.

В умовах, коли формувалися збройні сили у пострадянських державах, у російських офіційних виданнях з'явилися праці, в яких обгрунтовувалося 
твердження про недоцільність створення збройних сил у державах, які з'явилися внаслідок розпаду Радянського Союзу. Військовий фахівець С. Г. Мойсієв, обгрунтовуючи військово-правові основи співробітництва країн СНД, вважав за недоцільне, через економічні витрати, державам пострадянського простору мати свою власну армію [29]. На його погляд, керівники новостворених держав мали б укласти угоду 3 Росією про розміщення на їх суверенних територіях російських військ, регламентувавши їх правове становище. Цей же автор пропонував, щоб держави Співдружності об’єдналися в оборонний союз “на базі спільності інтересів і військовополітичних цілей”. Зрозуміло, що в цьому “об'єднаному союзі” мала б домінувати Російська Федерація. 3 метою підриву довіри до Збройних Сил України, внесення розладу серед особового складу російські політикани в інформаційних відомствах запустили версію про те, що скорочення Української армії відбувається на мовній основі: з армії звільняють начебто тих військових, які не володіли українською мовою [30, с. 46].

У середовищі вітчизняних дослідників утвердилося твердження, що наявна військова спадщина, яка стала власністю України в результаті розпаду Радянського Союзу, давала змогу створити потужну національну армію, здатну забезпечити безпеку та недоторканність державної території, а реалізація надлишкового майна, озброєння та військової техніки створювали передумови для отримання достатніх коштів, щоб забезпечити модернізацію Збройних Сил України. Військові навчальні заклади, що функціонували на території України, мали достатні можливості для підготовки фахівців для видів та родів військ Збройних Сил.

Між тим розпочата Росією збройна агресія проти України в лютому 2014 року показала, що Збройні Сили України опинилися на межі своєї боєздатності та належних спроможностей виконати головну функцію захистити територію своєї держави від зовнішнього ворога. Причини ослаблення боєздатності Збройних Сил України напередодні вторгнення Росії в Крим та російської збройної агресії на Сході України аргументовано 
аналізуються передусім у працях, підготовлених науковцями Національного інституту стратегічних досліджень [31]. Агресивний характер та мету російського керівництва щодо України розглянуто у праці Г. М. Перепелиці “Україна-Росія: війна в умовах співіснування” [22]. Дослідники доводять, що ослаблення обороноздатності держави обумовлені суттєвими прорахунками у процесі будівництва Збройних Сил України, що мали місце до 2014 року.

Законодавчі та нормативно-правові документи України передбачали формування Збройних Сил на базі радянських військових формувань, що перебували на українській території на час розпаду Радянського Союзу, шляхом їх поетапного скорочення і переформування на принципах розумної достатності. Однак вище керівництво держави, базуючись на суб'єктивних підходах, спираючись на миролюбний характер зовнішньої політики України та заперечуючи можливість зовнішньої загрози з боку Російської Федерації, надало перевагу процесу скорочення армії. Процес інтенсивного скорочення особового складу, озброєння та військової техніки перетворився на тенденцію, що діяла з середини 1993 року до початку 2014 року. У 2013 році після дворічної перерви була введена в дію Державна комплексна програма реформування i розвитку Збройних Сил на період до 2017 року, яка додатково планувала дострокову ліквідацію значної кількості органів військового управління, військових частин та особового складу [32]. Тільки 3 початком Революції гідності виконання заходів цієї програми було призупинено рішенням Ради національної безпеки і оборони України.

Вкрай негативно впливали на розвиток Збройних Сил України та їх боєздатність обмежені фінансові ресурси, які виділялися Збройним Силам України у 2010-2013 роках. 3 державного бюджету вони отримували менше $1 \%$ від валового внутрішнього продукту. При цьому понад 80\% від суми виділеного бюджету призначалися на утримання людського ресурсу Збройних Сил і лише незначні кошти на підготовку військовослужбовців, розвиток озброєння та військової техніки. Речове забезпечення військ у 2013 році фінансувалося на рівні 3\% від їх потреби. 3 причин низького рівня 
фінансування не виконувалися в повному обсязі основні державні оборонні програми. Саме через це були зірвані плани створення багатофункціонального ракетного комплексу, національного корвету для Військово-Морських Сил України, не завершено важливі розробки керованих авіаційних засобів ураження тощо. До того ж вкрай обмежене фінансування негативно впливало на авторитет армії та звужувало їі бойовий потенціал, а скорочення особового складу загострювало соціальну напругу в армійських колективах та відтік офіцерських кадрів, особливо молодшого офіцерського складу, що призвело до дефіциту командирів первинної ланки.

Дослідники роблять акцент на тому, що економічно розвинені країни у військовому будівництві позбавлялися застарілого озброєння, натомість збільшували видатки на оборону та переозброєння армії новітньою технікою та видами зброї, внаслідок чого бойовий потенціал їх армій зростав. Негативні соціально-економічні тенденції в Україні позбавляли її можливості йти таким шляхом. На озброєнні української армії у 2013 році налічувалося близько 4 тисяч одиниць важкого озброєння та військової техніки, третина 3 яких потребувала відновлення. Більша частина наявного озброєння та військової техніки була вироблена в 1980-1990 роках і була морально та фізично застаріла [1, с. 214]. Водночас у військах було багато надлишкового озброєння та військової техніки, які потребували значних фінансових та матеріальних ресурсів на їх утримання.

В історіографії стверджується, що ослаблення бойових можливостей ЗС України відбувалося протягом тривалого часу й особливо загострилося в 2011-2013 роках. Саме в ці роки далися взнаки антиукраїнська політика вищого державного керівництва щодо вирішення проблемних питань забезпечення обороноздатності держави. 32010 року по 2013 рік керувати Збройними Силами України призначалися особи, які взагалі не розглядали реформування армії як ключовий напрям своєї діяльності. Д. Саламатін, очолюючи Міністерство оборони України, звільняв 3 армії досвідчених фахівців, які мали належну освіту і досвід військової служби. Одночасно на 
ключові посади призначалися особи з близького оточення, які забезпечували йому вирішення насамперед бізнесових інтересів. Таку ж політику в армії проводив П. Лєбєдєв, призначаючи на відповідальні посади людей за критерієм особистої відданості. У діяльності Міністра оборони М. Б. Сжеля, за оцінкою правоохоронних органів, особливий інтерес був до матеріальних і фінансових потоків, зокрема поставок в армію нафтопродуктів і військового майна. Армія і їі офіцерський склад оцінювалися й сприймалися в державі через діяльність вищого військового керівництва, його ставлення до своїх обов'язків. У суспільстві формувалися негативні стереотипи щодо діяльності військового керівництва, руйнувався авторитет захисника Батьківщини, i, як наслідок, знижувався престиж військової служби.

Ослаблену увагу державного керівництва до життєдіяльності та боєздатності Збройних Сил України аналітики пояснюють і тим, що перманентна боротьба за владу та зіткнення інтересів представників різних соціальних верств суспільства, прихильників різних політичних сил призвели до того, що владна еліта почала вбачати у власному народові основну загрозу для владарювання. Тому в процесі формування і підтримки силових відомств преференції надавалися посиленню правоохоронних органів, а не Збройним Силам України [33, с. 8-9]. Така політика поряд з іншими ознаками свідчила про те, що в Україні створювалися передумови для встановлення тоталітарного режиму влади.

3 початком збройної агресії Росії проти України розпочався новий етап розвитку вітчизняної історіографії Збройних Сил України. Військові фахівці та науковці вбачають своє завдання в тому, щоб критично осмислити історію створення та розвитку Збройних Сил України в 1991 - початку 2014 роках, а на основі фактичних матеріалів, законодавчої та нормативної бази 3 урахуванням досвіду країн НАТО у зміцненні бойових спроможностей військ висвітлити процес реформування Збройних Сил України, а також досвід в антитерористичній операції та операції Об’єднаних сил на Сході України. 


\section{Список використаних джерел і літератури}

1. Обороноздатність України у XXI столітті. Виклики, загрози та шляхи їх подолання // Матеріали Парламентських слухань у Верховній Раді України 23 липня 2014 року [За заг. ред. I. М. Грабовенка]. - К. : Парламентське видавництво, 2014. - 344 с.

2. Папікян А.Л. До історії будівництва Збройних Сил України (19911999 р.) / А. Л. Папікян // Науковий вісник Національного університету “Львівська політехніка”. - 2007. - № 9. - С. 121-129.

3. Чорний В.C. Військова організація України: становлення та перспективи розвитку: монографія / В. С. Чорний. - Ніжин: ТОВ “Видавництво “Аспект-Поліграф”, 2009. - 368 с.

4. Кузьмук O.I. Формування та еволюція Воєнної організації (сектору безпеки і оборони) України (1991-2012) : монографія. - К. : НУОУ ім. Івана Черняховського, 2013. - $436 \mathrm{c.}$

5. Русначенко А.М. На шляху до національної армії (1989-1992) / А. М. Русначенко. - К., 1992. - 77 с.

6. Покотило O.I. Створення Збройних Сил України: історіографія : автореф. дис. ... канд. істор. наук / Олексій Іванович Покотило. - К., 2012. $20 \mathrm{c}$.

7. Збройні Сили незалежної України. Перші 10 років (1991-2001) / [Кол. авторів. За ред. В.В. Бринцева]. - К. : Видання академії, 2006. - 378 с.

8. Сокаль I.I. Будівництво Військ оборони повітряного простору України: перша спроба обєднання Військово-повітряних сил та Військ протиповітряної оборони (1991-1994рр.) / І. І. Сокаль // Вісник Національної академії оборони. - 2006. - № 2. - С. 50-53.

9. Куравський В.Г. Формування військ повітряної оборони України (1994-1996 рр.) / В. Г. Куравський // Воєнно-історичний вісник. - 2011. -№ 2. - C. $37-41$.

10. Рішення Колегії МО України від 12 квітня 2002 року про створення Повітряних Сил Збройних Сил України. 
11. Близнюков С.П. Хроніка створення Військово-Морських Сил України / С. П. Близнюков // Наука і оборона. - 2007. - № 3. - С. 19-22; Безкоровайний В.Г. Україна матиме свій флот! / В. Г. Безкоровайний // Військо України. - 1996. - № 1-2. - С. 10-13.

12. Нашивочніков О.О. Створення основ Військово-Морських Сил України (1991-1994 рр.) : автореф. дис. ... канд. істор. наук / Олександр Олександрович Нашивочніков. - К. : НУОУ, 2016. - 20 с.

13. Воробйов Г.П. Створення та розвиток Сухопутних військ Збройних Сил України (1991-2005 рр.) : автореф. дис. ... канд. істор. наук. - К. : HУOУ, 2014. - $18 \mathrm{c}$.

14. Ситник Г.П. Збройні Сили України в сучасних воєнно-політичних умовах / Г. П. Ситник // Військо України. - 1995. - № 7-8. - С. 10-13.

15. Галузевий державний архів Міністерства оборони України (далі ГДА МО України), ф. 4145, оп. 51219, спр.1, арк. 7, 8.

16. Дашкевич O.I. Вищий офіцерський корпус: історія створення та комплектування : монографія. - К., 2015. - 285 с.

17. Кобзар A.O. Становлення та розвиток структур виховної роботи у Збройних Силах України (1991-2011 рр.) : автореф. дис... канд. істор. наук. К. : НУОУ, 2013. -16 c.

18. Концепція оборони і будівництва Збройних Сил України, прийнята 11 жовтня 1991 року.

19. Довідка щодо державних програм будівництва, реформування та розвитку Збройних Сил України (1991-2011рр.).

20. Генеральний штаб Збройних Сил України: історія та сучасність / [Під заг. ред. С. О. Кириченка]. - К. : Прес-Кіт, 2007.

21. Касьянов Г. Україна 1991-2007: нариси новітньої історії : наукове видання. - К. : Наш час, 2008. - 432 с.

22. Перепелиця Г.М. Україна - Росія: війна в умовах співіснування. К. : Видавничий дім “Стилос”, 2015. - 880 с. 
23. Живиця Г.В. То був час напружений і відповідальний / Г. В. Живиця // Військово-історичний альманах. - 2001. - № 1. - С. 72-77.

24. Мамчак M.A. Україна: шлях до моря. Історія українського флоту / М. А. Мамчак. - Снятин : ПрутПринт, 2007. - 404 с.

25. Данілов А.П. Український флот: біля джерел відродження. - К. : Видавництво імені Олени Теліги, 2000. - 600 с.

26. ГДА МО України, ф. 3697, оп. 34747, спр. 1, арк. 421.

27. ГДА МО України, ф. 3697, оп. 34747, спр. 1, арк. 360.

28. ГДА МО України, ф. 3697, оп. 34747, спр. 1, арк. 449, 463-464.

29. Мойсеев С.Г. Международно-правовые основы сотрудничества стран СНГ / С. Г. Мойсеев. - М. : Юрист, 1997. - 260 с.

30. Захаров В.M. Военное стрительство в государствах постсоветского пространства / В. М. Захаров. - М. : РИСИ, 2011.

31. Світова гібридна війна: український фронт : монографія [За заг. ред. В. П. Горбуліна]. - К. : НІСД, 2017. - 496 с.; Власюк О. С. Кремлівська агресія проти України : монографія [О. С. Власюк, С. В. Кононенко]. - К. : НІСД, 2017, 304 c.

32. Державна комплексна програма реформування і розвитку Збройних Сил України на період до 2017 року, затверджена Президентом України від 2 вересня 2013 року № 479.

33. Лібанова Е. Україна у світі / Е. Лібанова, М. Дмитренко // Наукові записки інституту політичних i етнонаціональних досліджень імені I. Ф. Кypaca. - 2015. - № 5-6 (79-80). - C. 8-9. 
Shevchuk V.P., Doctor of Historical Sciences, Professor, Principal Researcher of Research Center of Military History of Ivan Cherniakhovskyi National Defense University of Ukraine (Kyiv)

\section{HISTORIOGRAPHY OF CREATION AND DEVELOPMENT OF THE ARMED FORCES OF UKRAINE IN 1991-2014}

The article covers the process of accumulation of historical knowledge about the creation and development of the Armed Forces of Ukraine in 19912014. It mainly analyzes the history of the creation of the Armed Forces, which significantly expanded and deepened the national military historiography. The article deals with the omissions and shortcomings in the construction of the Armed Forces of Ukraine, whose consequences directly influenced the temporary weakening of the military capabilities of the troops in the conditions of Russian armed aggression against Ukraine.

Keywords: Armed Forces of Ukraine, historiography, scientific publications, dissertation research, types of Armed Forces, fighting ability, creation, development. 